UDC $004.4+378+80$

Tetiana A. Vakaliuk

Doctor of Pedagogical Sciences, Professor, Professor, Department of Software Engineering

Zhytomyr Polytechnic State University, Zhytomyr, Ukraine.

ORCID ID 0000-0001-6825-4697

tetianavakaliuk@gmail.com

Olha O. Osova

Doctor of Pedagogical Sciences, Associate Professor, Associate Professor at the Foreign Philology

Department of the Municipal Establishment "Kharkiv Humanitarian Pedagogical Academy" of

Kharkiv Regional Council, Kharkiv, Ukraine

ORCID ID 0000-0001-7316-1196

osova.olga@gmail.com

Oksana A. Chernysh

PhD in Philology, Associate Professor at the Department of Theoretical and Applied Linguistics

Zhytomyr Polytechnic State University, Zhytomyr, Ukraine

ORCID ID 0000-0002-2010-200X

chernyshoxana@gmail.com

\title{
USING INFORMATION AND COMMUNICATION TECHNOLOGIES FOR THE FORMATION OF LINGUODIDACTIC COMPETENCE OF FUTURE FOREIGN LANGUAGE TEACHERS
}

\begin{abstract}
The article explores the use of information and communication technologies for the development of future foreign language teachers' linguodidactic competence. On the grounds of the analysis of the scientific and pedagogical literature the authors have proved the topicality and importance of applying information and communication technologies in future foreign language teachers' training. The empirical methods (questionnaires, observation, surveys) were used to determine the current situation with the application of information and communication technologies in the process of future foreign language teachers' professional training. The essence of the key notions of the research has been specified: "information and communication technologies", "professional and pedagogical competence", "future foreign language teachers' linguodidactic competence". The experience of applying information and communication technologies in the process of training foreign language teachers has been presented, as the abovementioned technologies have been proved to be an important means for the formation of future foreign language teachers' linguodidactic competence. It has been determined that educational information and communication technologies (multimedia presentations, cloud services, blog, video scribing, e-portfolio, web-quests, etc.) provide unique didactic possibilities to form future foreign language teachers' linguodidactic competence, namely: create conditions for working with foreign language business documents, modeling virtual environment for foreign language business communication, obtaining linguistic and extralinguistic information, contribute to all types of speech activity (reading, speaking, listening, writing), presenting and looking for data on languages and countries, etc. Particular attention has been paid to such kind of work with information and communication technologies as creating personal e-portfolios, which demonstrate creativity, innovativeness and professional competence of the modern teacher and develop future teachers' self-presentation and self-reflection skills. There has been determined and experimentally proved the effectiveness of using information and communication technologies in the formation of future foreign language teachers' linguodidactic competence.
\end{abstract}

Key words: information and communication technologies; linguodidactic competence; future foreign language teachers; e-portfolio. 


\section{INTRODUCTION}

Defining the niche. Significant changes in the system and structure of education in Ukraine, its integration into European educational area, the dynamics of scientific and technological revolution and world modernization, the need for rapid adaptation in an information technology society contribute to the development of a new generation of teachers. The 21 st century teacher should be ready to cooperate with real and virtual partners using information and communication technologies (ICT) for productive professional performance.

In the context of European interaction and integration of foreign languages knowledge in all spheres of human activity, the training of future foreign language teachers is of particular significance. It requires special scientific reconsideration of the system of values, formation of professionally significant qualities of foreign language teachers.

The importance of ICT in the organization of the educational process aimed at training a new generation of professionals in the field of education, development of their pedagogical, linguistic and digital competencies, preparation for life in the modern information society, is featured in the Laws Of Ukraine "On Education" (2017) [1], "On Higher Education" (2017) [2], "National Strategy for Education Development in Ukraine for 2012-2021" (2012) [3].

According to the regulations mentioned above, a foreign language teacher is expected to have sufficient linguistic knowledge and highly developed speaking skills. Moreover, a language teacher should undergo a thorough theoretical and practical training to ensure European quality of education, transition to innovative forms and methods of organizing the educational process and ICT implementation.

The introduction of ICT in foreign language teachers training contributes to philology students' quality education. Furthermore, it facilitates ICT skills development and ensures their use in future professional and pedagogical activities. At the same time, the pilot study results show that $52.2 \%$ of future professionals do not have enough information about the didactic potential of ICT in foreign language learning. What is more, only $41.3 \%$ of teachers are aware of the need to develop philology students' skills in using ICT in their future professional and pedagogical activities. As it turned out, they use only a limited range of these technologies.

Therefore, ICT use in the development of future foreign language teachers' linguodidactic competence is an integral part of their professional pedagogical competence. Today it acquires a particular significance.

Analysis of recent research and publications. The issue of education informatization and the definition of ICT theoretical principles in the educational process of higher education institutions has been studied by many scholars, namely V. Yu. Bykov [6], V.P. Bespalko [7], I.V. Gavrish [8], O.G. Glazunova, O.G. Kuzminskaya, T.V. Voloshin, T.P. Sayapina, V.I. Korolchuk [9], M.I. Zhaldak [10 ], E.S. Polat [11], O.M. Spirin [12] and others.

A significant contribution to ICT use studies has been made by I.I. Kostikova, A.O. Maslyuk [13], I.A. Khyzhnyak [14], O.A. Kucheruk, S.O. Karaman, O.V. Karaman, N.M. Vinnikova [15], N.V. Morse, O.G. Kuzminskaya, V.P. Wember, O.V. Barny [16], S.O. Semerikova [17], V. Yu. Bykova [18], O.G. Romanovsky and many others [19]. The scientists have proposed the conceptual provisions and identified distinctive features of ICT. Furthermore, they have presented the methodology of educational process computerization and highlighted the ways to solve theoretical and practical problems of IT use in the educational process.

In addition, the scholars have identified the means of information and communication technologies, determined the role and place of information technologies in the educational process and estimated their use in training. 
The use of ICT in teachers' professional training has been studied by V. Yu. Bykov [6], O.A. Dubaseniuk [20], I.I. Kostikova [21], L.I. Morska [22]. V. Yu. Bykov claims that ICT use radically changes the role and place of teachers and students in the educational process $[17$, p. 2].

I.I. Kostikova admits that the change of teacher's role and the role of computers in the implementation of education, respectively, requires changes in teaching methodology. In this regard, the researcher identifies and describes the didactic functions of the teacher that could be performed by a computer (training, control, management, organizational functions). The scholar also highlights a significant advantage of a computer in performing certain educational functions (machine as a modulator, machine as a tutor etc.) [21, p. 15-16].

Undoubtedly, ICT use in the system of teachers' professional training has a number of advantages. Thus, it leads to serious reconsideration of traditional methods of teaching philological disciplines as well as the role of future teachers' professional training in the context of ICT potential.

L.I. Morska emphasizes the importance of ICT use in process of future teachers' professional training. In the study [22, p. 24], the scholar highlights that preparation of future foreign language teachers for IT use in their professional activities can be done through IT implementation in teaching. In addition, she develops a method of foreign language teachers' training aimed at IT use in teaching students.

N.V. Morse views ICT as "a tool for educational activities of those people who improve or change their qualifications" [16, p. 49]. The scholar emphasizes the unique role of the ICTbased approaches to educational process organization.

However, literature review reveals a gap in the study of the specificity of ICT tools integration into the system of future foreign language teachers' professional education. Correspondingly, future foreign language teachers' linguodidactic competence development requires a deeper study.

Therefore, the aim of the article is to explore the possibilities of ICT use in future foreign language teachers' linguodidactic competence development.

\section{THEORETICAL FUNDAMENTALS OF THE RESEARCH}

Education informatization and ICT introduction in the educational process ensures a qualitatively new level of future foreign language teachers' training. Systematic integration of ICT tools presupposes a gradual transition to an innovative system of training as a necessary condition for education informatization in accordance with the "National Doctrine of Education Development in Ukraine" [23].

The importance of ICT use in the process of future foreign language teachers' training has been emphasized by prominent Ukrainian and foreign scholars. Thus, L.I. Morska views ICT use in the process of future foreign language teachers' training as a search for the ways to solve the following problems: creating authentic language content; organizing independent work, speech drill in particular; processing target language texts; avoiding routine, mechanical, and time-consuming work for teachers; creating authentic language environment; promoting foreign language study as a means of obtaining educational and professional information [22, p. 17].

I.I. Kostikova and A.O. Maslyuk view ICT as a system of methods and techniques that provide collection, accumulation, storage, processing, transmission and display of information based on computer technology and computer networks use [13, p. 68].

In pedagogical sciences (V. Yu. Bykov, O.V. Spivakovsky, O.M. Spirin, I.A. Khyzhnyak), there are certain classifications of ICT according to their purpose. In this study, we pay attention to ICT educational purposes, which involve the use of computers, 
computer-based learning tools and computer communication networks to solve didactic tasks [14, p.141].

ICT in education are based on the use of electronic educational resources, which are divided into: instructional (multimedia presentations, textbooks, manuals, normative educational documentation on language and linguistics, guidelines, linguistic workshops, visual aids, etc.); content-driven (dictionaries, directories, encyclopedias, archives, repositories, portfolios, etc.); network dependent (distance courses, webinars, video conferencing, etc.); assessment oriented (tests, tasks) [14, p. 219-221].

The main function of ICT in education is to ensure optimal conditions for solving priority pedagogical tasks. One of such tasks is the development of future teachers' key competencies to solve problems in professional, social and everyday life [15].

A special role in the context of future teachers' training is given to professional pedagogical competence that contributes to specialists' constant professional development.

Recent studies prove that foreign language teachers' professional pedagogical competence is integrative and includes professionally important qualities and competencies that contribute to productive professional pedagogical activities.

Unquestionably, one of the most important aspects of philology students' professional training presupposes thorough knowledge and well-developed skills in the field of Linguistics. Moreover, students should get a profound training in methods of teaching. Therefore, the research considers future teachers' linguodidactic competence as an important component of their professional pedagogical competence.

Linguodidactic competence of a foreign language teacher is characterized by significant variability in determining its content and structural components [14; 24; 25]. Thus, N.M. Ostapenko emphasizes that linguodidactic competence is closely connected with acquiring knowledge and the development of skills to critically evaluate the object, subject, content, and structure of linguistic disciplines. In addition, great significance is given to principles, tools, methods and technologies of training [24].

O.A. Kopus defines didactic competence as a set of knowledge, skills, and experience of evaluative attitude to the subject, object, content and structure of linguistic and linguodidactic disciplines. Therefore, the scholar emphasizes the importance of developing philology students' skills in applying the principles, methods, techniques, tools and forms of teaching languages. The researcher views such skills as an important integrated characteristic of future teachers' personality [25, p. 85].

I.A. Khyzhnyak strongly supports the idea of foreign language teachers' linguodidactic competence development. The researcher emphasizes the need for future teachers' continuous self-improvement as a necessary condition for their high quality professional performance [14].

However, despite all terminological diversity, the characteristics of linguodidactic competence do not contradict each other. They are interconnected and complementary, which makes their application possible both separately and in a complex.

Considering current approaches to foreign language teachers' linguodidactic competence, we view it as a component of professional pedagogical competence, which is an integrative property, manifested in the set of didactic and subject-related (foreign language) competences.

Literature review on linguodidactic competence composition $[15 ; 20 ; 25]$ gives the possibility to single out the following components: - motivational (motives, intentions, aspirations, orientation), which ensures a constant interest in foreign language learning; linguodidactic (the ability to observe literary norms, lexical and phonetic rules; the knowledge of target language morphological and syntactic peculiarities; IT skills); - reflective, which is 
manifested in the ability of future foreign language teachers to reflect on their own linguodidactic activities.

\section{RESEARCH METHODOLOGY}

To accomplish the aim of our research, we have used:

theoretical methods: analysis, comparison, systematization of the scientists' ideas to determine distinctive features of ICT; psychological and pedagogical literature review on future foreign language teachers' linguodidactic competence development;

empirical methods: observation of the work of higher education institutions teachers, a pilot research to assess ICT use in future foreign language teachers' linguodidactic competence development; the assessment of students' awareness of ICT potential in foreign language learning; questionnaires, surveys, discussions, observations, generalizations and analysis of pedagogical experience in the system of higher pedagogical education to assess the level of future foreign language teachers' linguodidactic competence development;

a method of statistical data processing based on Pearson's criterion to identify the most effective means of ICT in future foreign language teachers' linguodidactic competence development.

To analyze the specificity of ICT use in future foreign language teachers' professional training, 93 philology students of the Faculty of Social and Pedagogical Sciences and Foreign Philology at Kharkiv Humanitarian Pedagogical Academy did the questionnaire.

The questionnaire included the following questions:

1. How often do you use ICT preparing for seminars and practical classes (always, sometimes, never)?

2. What types of ICT do you use in preparation for foreign language classes?

3. What types of ICT are most often used by teachers in vocational disciplines? never)?

4. Do you use your higher education institution electronic library (always, sometimes,

5. Do you understand the material better if it is accompanied by sound, dynamic images and graphics?

6. What form of study do you prefer (lecture-monologue, lecture with elements of dialogue, interactive lecture using ICT)?

7. Is it mandatory to use ICT in foreign language teaching (yes, preferably not)?

8. What types of ICT, in your opinion, have the greatest didactic value in future foreign language teachers' professional training?

9. Do you plan to use ICT in your future professional and pedagogical activities?

10. How much do you know about the organization of foreign language learning using ICT (enough, not enough, nothing)?

In addition, to clarify the students' attitude and identify their potential interest in ICT use in future professional activities, the students were asked to write an opinion essay "The 21 st Century Teacher" and participate in a roundtable discussion "Teaching Foreign Languages in Digitalization of Education", held on the occasion of Science Day in Ukraine.

\section{RESEARCH RESULTS}

The study presents a comprehensive and systematic analysis of ICT use in future foreign language teachers' linguodidactic competence development. The investigation was carried out in three stages: - motivational stage (experimental work aimed at understanding students' need for theoretical knowledge and feasibility of ICT use in foreign language 
training); - training and activity stage (aimed at improving the system of linguistic knowledge and skills and effective ICT use in future professional and pedagogical activities); - reflection stage aimed at the development of students' self-presentation, self-assessment and selfcorrection skills.

Thereafter, the students of the Faculty of Social and Pedagogical Sciences and Foreign Philology at Kharkiv Humanitarian Pedagogical Academy took part in group and individual interviews about ICT use in vocational disciplines teaching as well as the potential interest in ICT use in future professional and pedagogical activity.

The research results (Fig. 1) show that ICT use is an important prerequisite for students' effective independent work. Thus, $87 \%$ of the students say that they almost always use ICT in preparation for seminars and practical classes in vocational disciplines. Unquestionably, the most widely used ICT means among the students are computers, laptops, Internet, tablets, smartphones and others. Correspondingly, the teachers prefer to use computer tests, multimedia, computers and projectors to train future foreign language teachers.

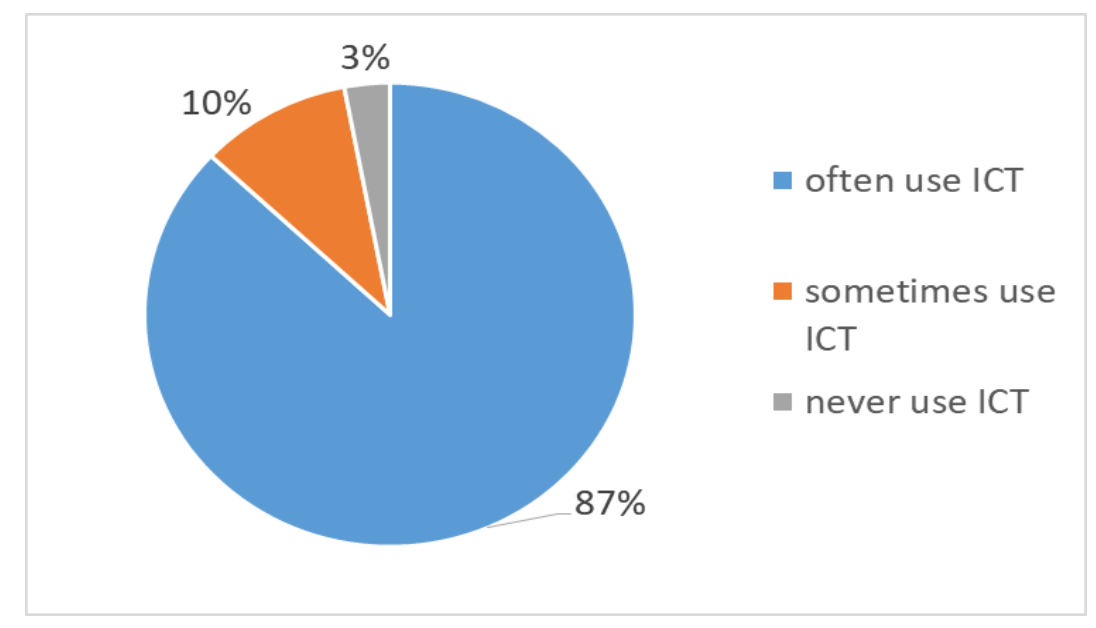

Fig. 1. ICT use in preparation for classes

The respondents emphasize the importance of using sound and dynamic images in foreign language learning. Accordingly, philology students are greatly interested in interactive lectures involving different ICT tools (78\%), and lectures with dialogic elements (16\%). Only some students (6\%) prefer lectures-monologues (Fig. 2).

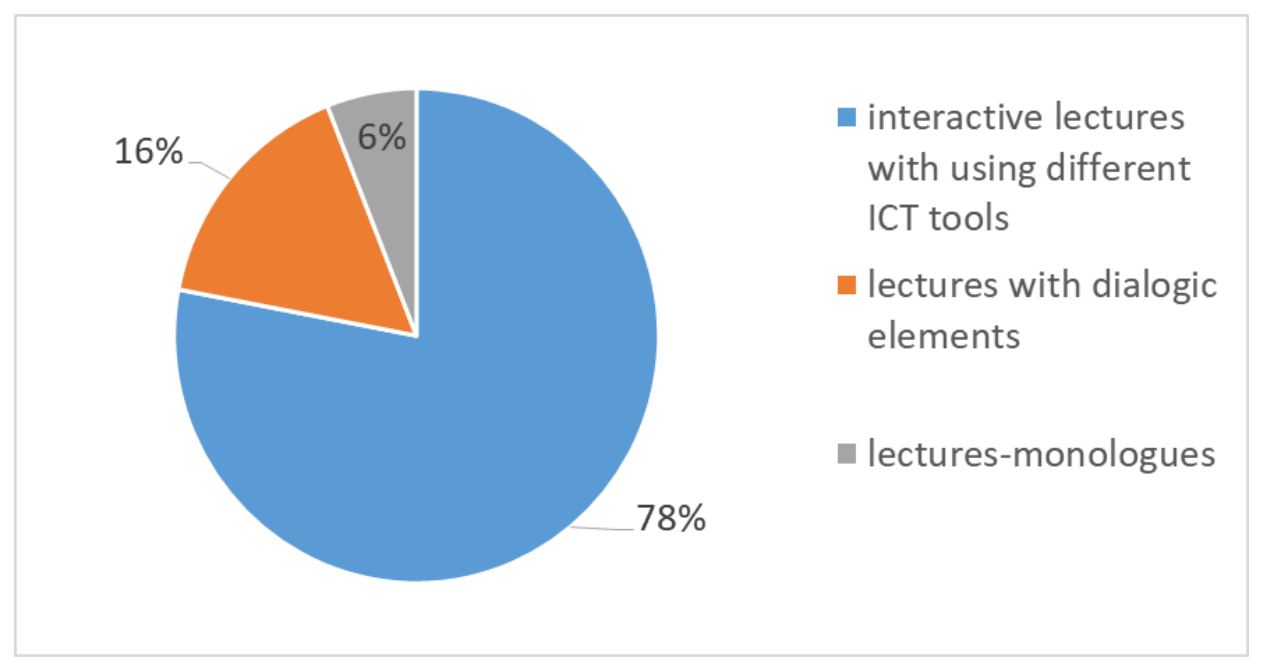

Fig. 2. Effective forms of education 
Students with passive information processing usually have a low level of activity and success and do not show much interest in learning.

Furthermore, most of the students (83\%) highlight the significance of ICT use in foreign languages teaching. Some learners $(10 \%)$ consider ICT desirable in future foreign language teachers' training. However, the others (7\%) claim that ICT use is optional if there is an option to communicate with native speakers (Fig. 3).

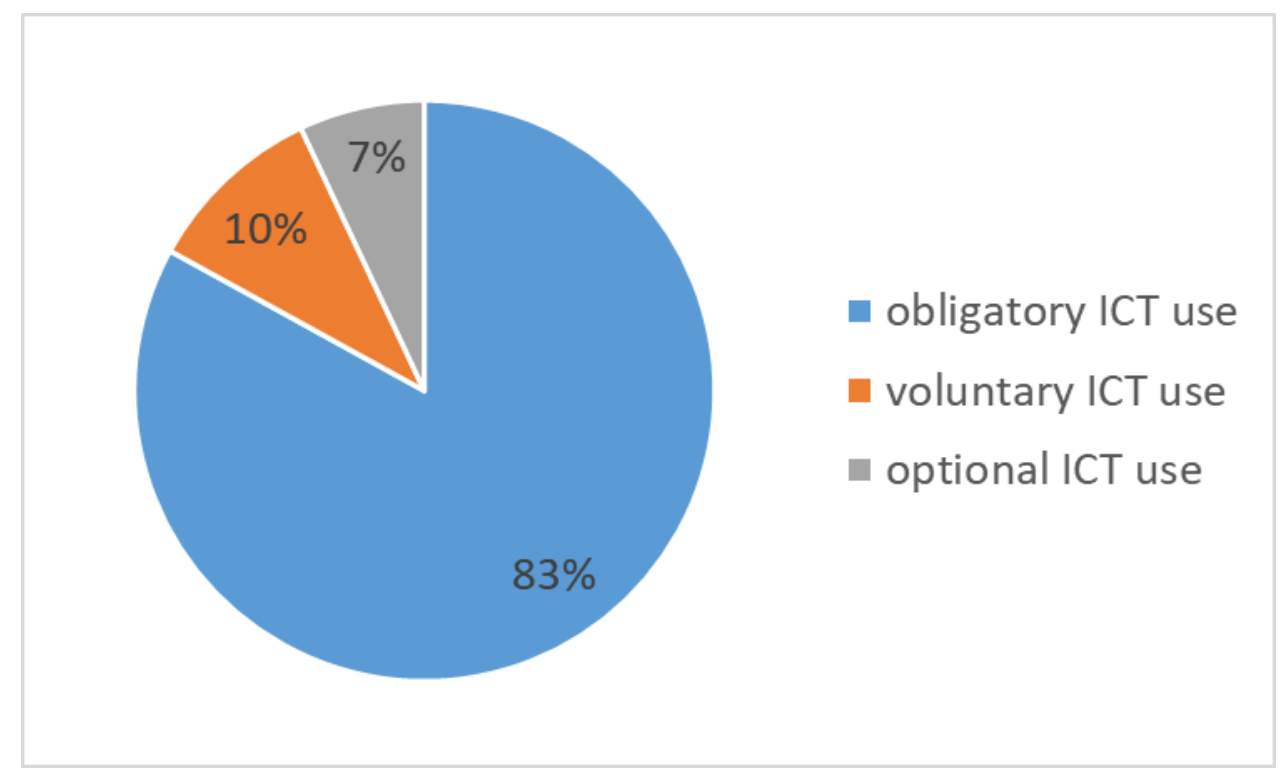

Fig. 3. ICT use in foreign languages learning

The respondents are greatly interested in the use of various ICT tools, namely the Internet (67\%), computers (17\%), and multimedia (16\%) (Fig. 4).

Survey data analysis proves that the respondents strongly believe in the importance of ICT use and view it as "a modern learning tool", "an important learning tool in modern education system", and "one of the most necessary learning tools in the survival kit of a teacher-innovator” etc.

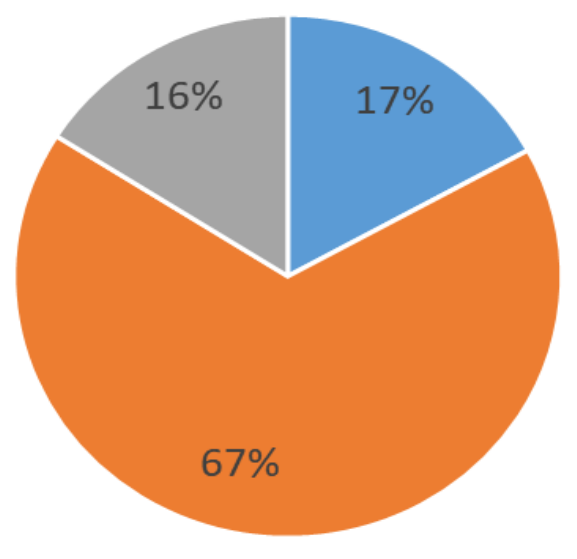

computers

Internet

multimedia

Fig. 4. ICT tools in foreign languages learning 
Moreover, most of the students (89\%) are curious about the full potential of ICT use in foreign language classes. Due to constant scientific and technological progress, it is greatly important to develop ICT skills on a regular basis. Rapid development of ICT leads to an increase in their types and number. Therefore, it becomes difficult to choose the most optimal and professionally oriented resources for a specific learning goal. Correspondingly, one of the most important tasks of a modern foreign language teacher is to provide relevant information on ICT, which has a wide range of didactic opportunities and can be used to maximum advantage in philology students training.

ICT introduction in future foreign language teachers' linguodidactic competence development starts with the formation of its motivational component. The basis for determining this component lies in the positive impact of motivation on students' productivity, development and self-development. The motivational component is formed by the motives of professional creativity, the desire for success, the need for professional realization through ICT, disclosure of creative potential, desire to master ICT tools and use them creatively in future professional activities, job satisfaction etc. To activate the motivational component, we should conduct a lot of activities to increase the level of students' motivation to use ICT in their future work (training sessions on overcoming insecurity and demotivation, on the specificity of ICT use in foreign language teaching, psychological barriers; round tables on the importance of ICT use in the process of foreign language learning).

The second stage of the research was dedicated to students' grammar, vocabulary and pronunciation skills development. Here, we used a bulk of effective Internet services, special programs, Web 2.0 resources, digital dictionaries and encyclopedias, etc. Unquestionably, ICT didactic functions and potential greatly contribute to the didactic component of future foreign language teachers' linguodidactic competence development.

One of the most vivid examples of ICT use in foreign language learning is the integration of cloud services (as a type of ICT) into educational process. It helps to create clouds of words ("tag clouds") (WordArt, Wordcloud, Wordle.net, Word ItOut, etc.), which perform informative, training, and controlling didactic functions.

Work with "clouds" undergoes several stages, namely the introduction of the concept, the definition of keywords by input parameters, the choice of the image of "clouds" in accordance with the topic, and the creation of "clouds". With the help of these services, it becomes possible to create a visual presentation of the topical vocabulary, regular and irregular verbs, exceptions to grammar rules etc. Moreover, students like to make up their own stories, fairy tales, or write wishes or greetings in the form of a "cloud of words".

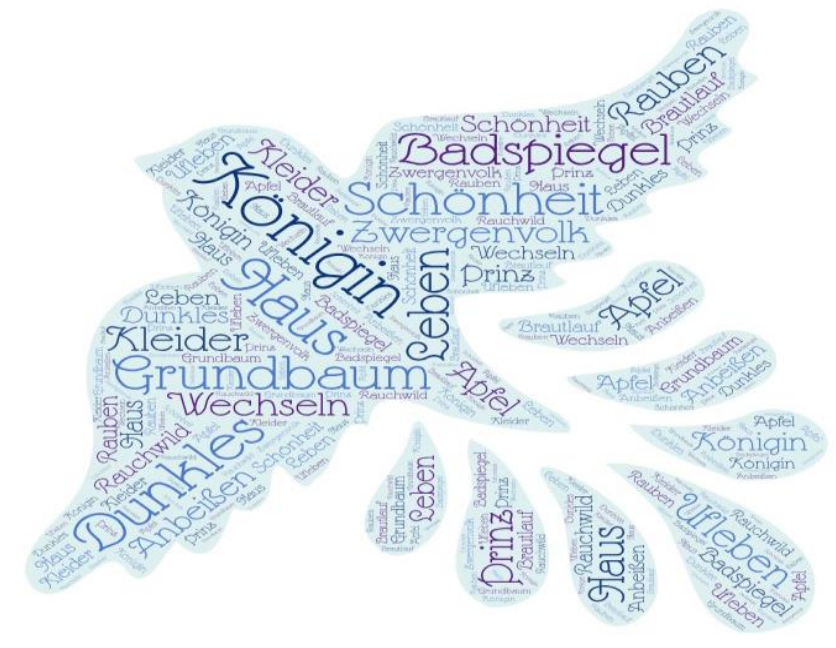

Fig. 5. Word Cloud on "Dornröschen” written by Brothers Grimm 
The cloud service significantly contributes to students' skills development in terms of writing an essay on the topic suggested, choosing appropriate topical vocabulary items, as well as doing creative tasks etc. Undoubtedly, "tag cloud" makes students motivated and enables them to present ideas clearly by means of providing a sufficient visual support (see Fig. 5).

Such an innovative way of textual information visualization greatly contributes to new material perception and memorization, students' vocabulary skills development and facilitates learners' creative thinking. Working with the "cloud", students identify keywords, select and create certain images with the help of associations. What is more, "clouds" vary in color, word positions as well as other patterns, namely characters, emblems, logos, symbols that contribute to students' better understanding.

Such services have great didactic potential in future foreign language teachers' linguodidactic competence development. They provide new material visual presentation in the form of a "cloud", with the basic concepts, rules and exceptions. Moreover, they foster students' writing skills development inspiring learners to create their own texts or reference notes on the topic in the form of "clouds". In addition, these tools form the ability to identify lexical material on relevant topics and present it in the form of "clouds" with key phrases and concepts.

Unquestionably, each "cloud" is unique, as the service allows students to show their creativity as well as develop their ICT skills, which significantly contributes to their future professional and pedagogical activities. Therefore, ICT use provides an opportunity to control students' linguistic skills development.

One of the most productive information and communication tools for data visualization is video scribing. Video scribing is widely used in future foreign language teachers' training at Kharkiv Humanitarian Pedagogical Academy. It presupposes the use of special programs (PowerPoint, PowToon, GoAnimate, SparkolVideoScribe, Animaker) to create videos or video animations to support students' or teachers' speech or text material. Thus, new grammar material is efficiently presented and explained with the help of scribing facilitation. The study proves that students understand the material better and faster when visual data (VideoScribe service) are used in teaching grammar.

Moreover, video scribing significantly contributes to ICT future foreign language teachers' skills development. Thus, the second-year students of the Faculty of Social and Pedagogical Sciences and Foreign Philology were given the task to create video animations for the tales written by Brothers Grimm. A screenshot of students' video presentation is given in Figure 6.

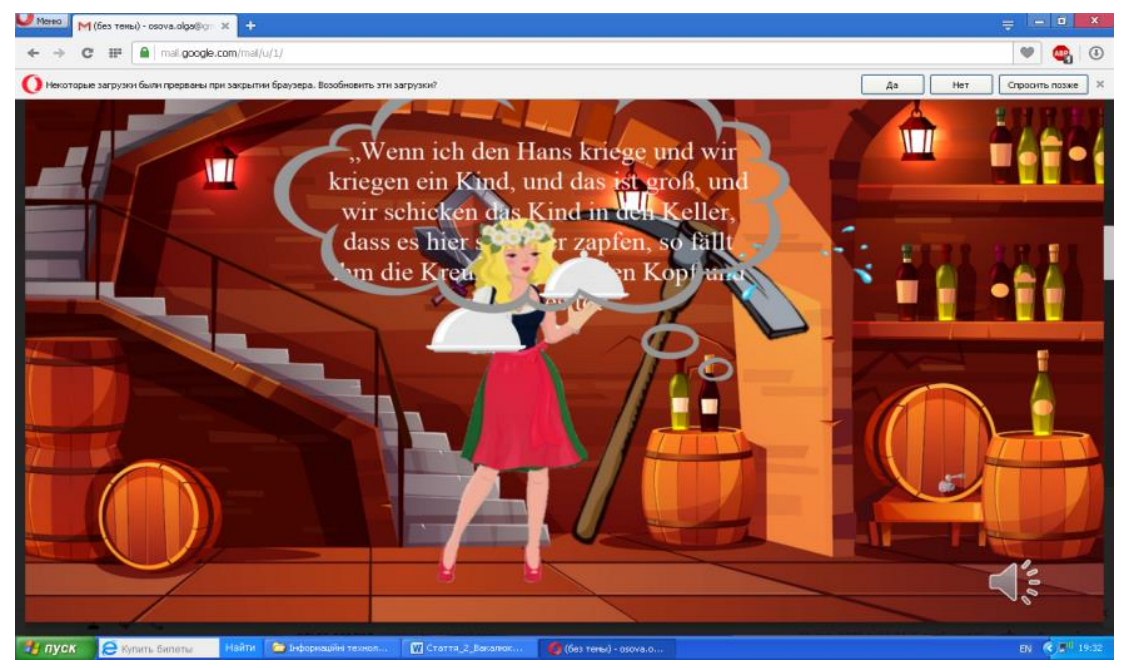

Fig. 6. "Smart Elsa” by Brothers Grimm 
The video was accompanied by a brief summary of the fairy tale, the main characters presentation, and key characters' speeches. Thus, with the help of video scribing it was possible to make students interested in the literary heritage of German poets and storytellers, to facilitate learners' understanding of new grammar phenomena, to develop ICT skills in teaching philological disciplines, as well as to control and manage the process of learning linguistic material.

Web2.0 resources are effectively used to form future foreign language teachers' linguodidactic competence. Thus, a blog can be used in learners' classroom and extracurricular activities to develop future foreign language teachers' skills. Such a blog was created on the Wordpress platform (https://wordpress.com/view/wordpresscomstartgeschaftsdeutsch.wordpress.com) to foster the formation of a didactic component of future foreign language teachers' linguodidactic competence development in the context of Business German. The blog consists of the following sections: a methodological kit, an electronic library, useful links, a portfolio, and a feedback.

These sections presented on the pages of the blog "Business German" provide quick access to relevant electronic resources: dictionaries, reference books, manuals in digital format, videos, and useful hyperlinks. All this contributes to the didactic function of this electronic resource.

Special attention should be given to the sections "Methodological kit" and "Feedback" that contain guidelines on the discipline, necessary for the future specialists' professional activity. "Methodological kit" is a set of engaging exercises and didactic games aimed at developing future foreign language teachers' skills in designing a methodologically balanced lesson, taking into account the relevant didactic functions and capabilities of modern ICT when teaching a foreign language. "Feedback" section gives students the opportunity to communicate with the teacher, receive comments, advice and guidance in accordance with the objectives of the course.

The section "Electronic Library" contains lecture notes, textbooks and manuals, dictionaries, etc. Learners have the opportunity to get acquainted with linguistic and theoretical course data. Moreover, they can do some drill exercises to practice their speaking skills as well as business communication skills. All in all, blogs as educational recourses have a great potential in teaching Business German. They greatly contribute to creating and processing business documents, modeling a virtual business environment in a foreign language, obtaining linguistic and extralinguistic information. In addition, they foster the development of students' reading, speaking, listening and writing skills. Furthermore, they facilitate learners' ability to find and present quality information on languages and countries. What is more, they improve the understanding of ICT didactic potential in future professional activity.

Special significance should be also given to webquests that contribute a lot to linguodidactic component formation. A webquest has a classic structure proposed by E.S. Polat, namely, introduction, which states the topic, description of the main participants' roles, quest script, task and questions on phraseology, which students should do independently, hyperlinks to information resources, reference books, encyclopedias, etc., necessary to do the tasks, tasks guidelines, and assessment [11].

Thus, the Deutsche Idiome webquest (see Figure 7) helps to develop students' theoretical skills in phraseology by means of doing practical exercises (match phrases with pictures, watch videos and take an online test, follow a hyperlink to phrase dictionaries and answer questions about idiomatic expressions meaning etc.). 


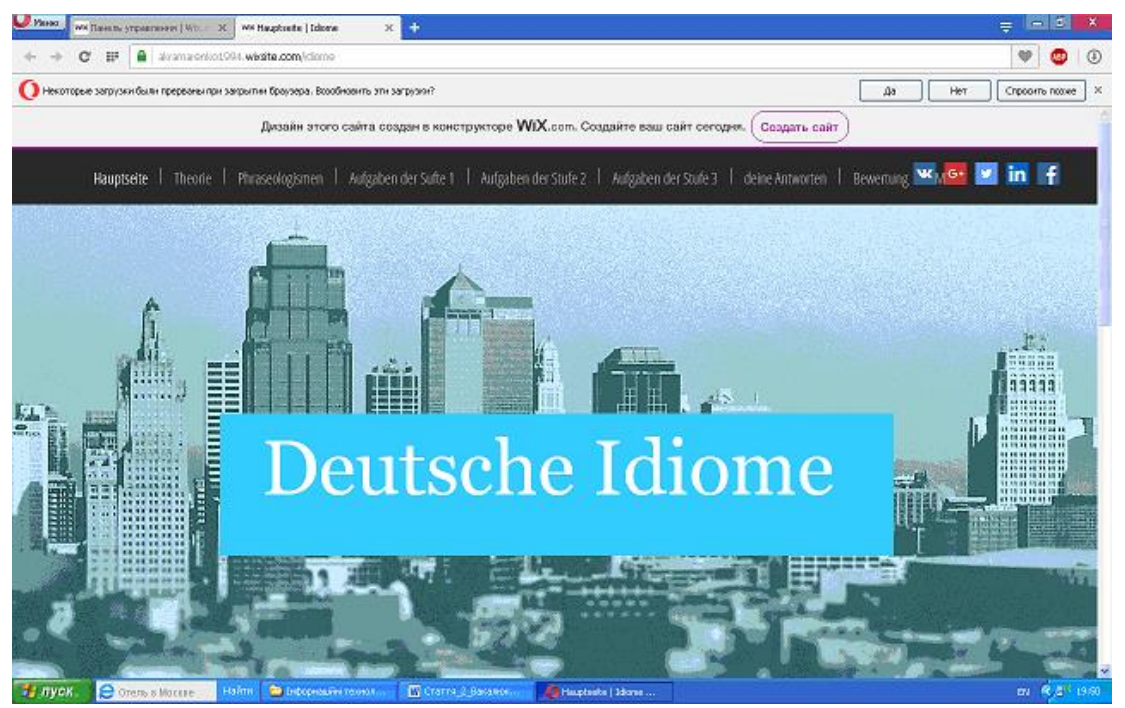

Figure 7. Webquest main page.

The introduction of the Deutsche Idiome webquest has greatly contributed to the creation of a new innovative educational space. It has opened new didactic opportunities for future foreign language teachers' linguodidactic competence development. It expands theoretical knowledge of foreign language phraseology and provides training in the use of idioms in a particular context; stimulates speaking skills development by doing interactive tasks; teaches to analyze and systematize the information from reference sources, etc. In addition, due to the integration of this educational information resource in future foreign language teachers' training, students get technical knowledge and skills to work with webquests, which they will definitely need in their future work. To accomplish all the above mentioned tasks, it is also relevant to organize the competition for the best students' webquest.

Among other information and communication resources that we use in future foreign language teachers' linguodidactic training, we should also mention Google services. Google services enable students to make Google presentations, and implement cooperative forms of work using ICT, working with cloud environments, digital libraries, etc.

The third stage of the study was dedicated to the use of an electronic portfolio, which greatly contributes to the formation of a reflective component of future foreign language teachers' linguodidactic competence development. Nowadays, having your own portfolio is an indicator of teachers' creativity and highly-developed professional competence.

With the help of the tilda.ws website designer, students created their own electronic portfolios (http://boikoeng.tilda.ws, http://projekt1866846.tilda.ws/, http://taranina.tilda.ws/taraninalearning, etc.). The portfolios include the following structural elements: general information, research and methodological activities. To create a sufficient portfolio, students need to generalize, correctly use grammar and speech constructions. Moreover, it significantly contributes to students' self-assessment.

Electronic portfolios enable future teachers to thoroughly reflect on their academic and professional achievements, demonstrate knowledge and skills, as well as the level of didactic skills mastery. In addition, they facilitate the development of communication skills and selfpresentation skills which are very important for the future foreign language teachers' professional activity. Therefore, this resource is an effective tool for future teachers' linguodidactic competence development.

As a result, the effectiveness of ICT use in linguodidactic competence development has been tested. For this purpose, at the beginning of ICTs implementation, experimental and 
control groups (EG and CG) were formed in accordance with the assessments in a foreign language based on the results of the school certificate (statistical equivalence of these groups was checked using the Kolmogorov-Smirnov criterion). 46 students were involved in CG, and EG included 47 students.

In CG the training was carried out according to the usual method of training. In EG ICT was used.

To test the pedagogical feasibility of ICT, we measured the state of future foreign language teachers' linguodidactic competence development in control and experimental groups, which showed that there was an increase in \% of EG students compared to \% of students in CG with high and sufficient level of future foreign language teachers' linguodidactic competence for each component (Fig. 8):

the motivational component: at a sufficient level in EG from $22 \%$ to $40 \%$; in CG - from $18 \%$ to $26 \%$; at a high level in EG from $7 \%$ to $23 \%$; in CG - from $5 \%$ to $10 \%$;

the linguodidactic component: at a sufficient level in EG from $17 \%$ to $51 \%$; in CG from $19 \%$ to $27 \%$; at a high level in EG from 6\% to $12 \%$; in CG - from $6 \%$ to $8 \%$;

the reflection component: at a sufficient level in the EG from $14 \%$ to $31 \%$; in CG - from $12 \%$ to $17 \%$; at a high level in EG from $8 \%$ to $15 \%$; in CG - from $5 \%$ to $7 \%$.

Taking into account these data, it is concluded that ICT use in future foreign language teachers' training has a positive effect on increasing the percentage of students in the experimental group whose language didactic competence is formed at a high and sufficient level.

To substantiate the conclusions, statistical processing of the obtained data was used. The results obtained with Pearson's $\chi 2$-test show that the samples have statistically significant differences, i.e. ICT use is more appropriate in foreign language teaching than in traditional teaching. Thus, ICT use is effective for future teachers' linguodidactic competence development.

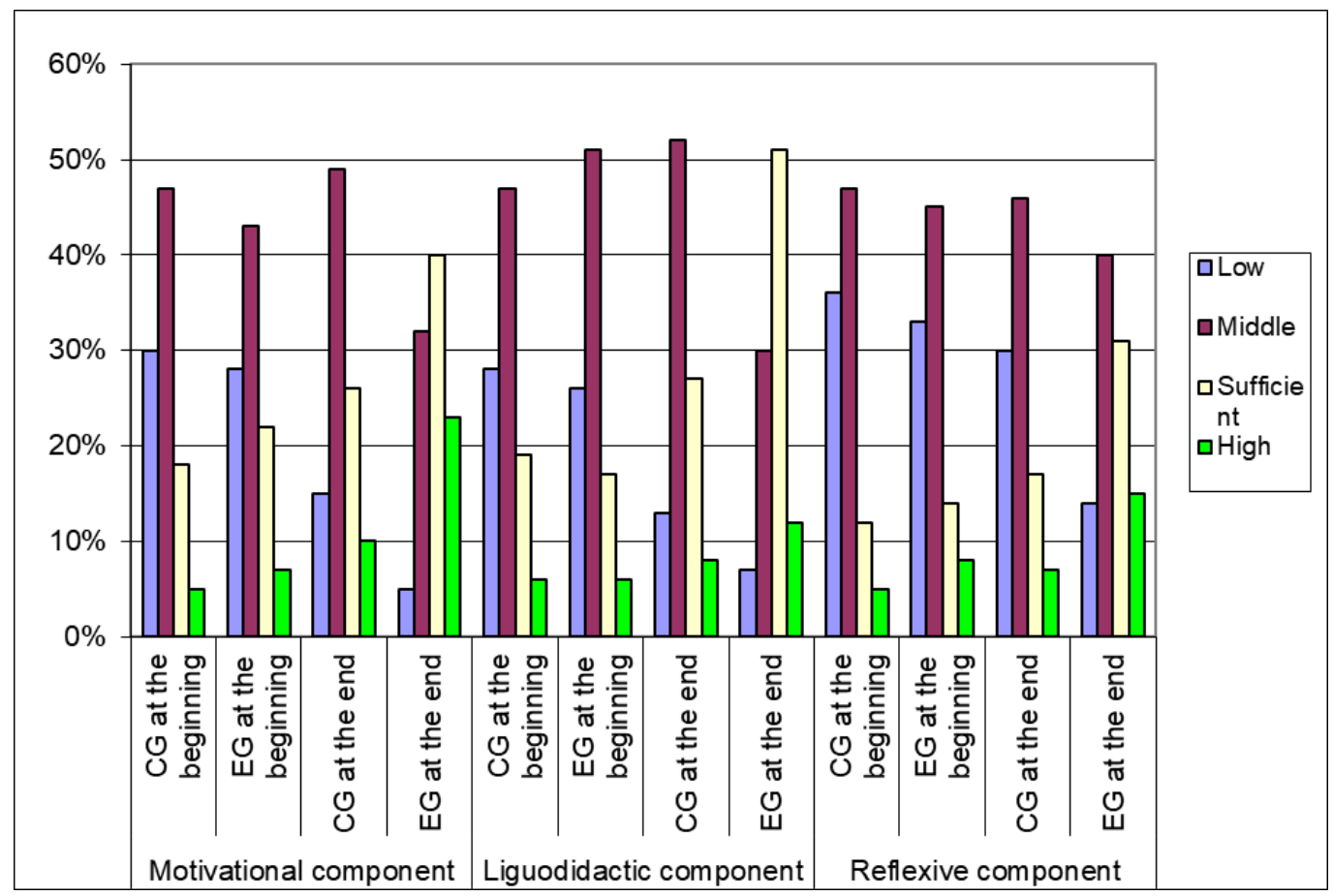

Fig. 8. Comparative distribution of students in $C G$ and EG in the context of linguodidactic competence development at the beginning and at the end of ICT implementation in educational process 


\section{CONCLUSIONS AND PROSPECTS FOR FURTHER RESEARCH}

Based on the analysis of the existing research, ICT is interpreted as a system of methods and techniques that provide collection, accumulation, storage, processing, transmission and display of information based on computer technology and computer networks (I. Kostikova, A. Maslyuk).

The study pays special attention to ICT use for educational purposes, based on the use of electronic educational resources (multimedia presentations, e-textbooks, linguistic workshops, visual aids, directories, encyclopedias, e-archives, repositories, portfolios, distance learning courses, webinars, videoconferencing, assessment tools, such as tests, tasks), which perform an important didactic function in future foreign language teachers' training.

Unquestionably, ICT is one of the most important means of foreign language teachers' linguodidactic competence development. Linguodidactic competence is a component of professional pedagogical competence.

The research proves that ICT use in future foreign language teachers' professional training facilitates students' progress and fosters the development of their professional competencies. The survey results signify the need to expand the range of types of ICT in organizing foreign language teachers' professional training and in their linguodidactic competence development.

The investigation proves that complex ICT use is aimed at the formation of motivational, linguodidactic and reflexive components of foreign language teachers' linguodidactic competence development.

ICT use in educational process provides significant didactic opportunities for linguodidactic competence development. Thus, the introduction of Internet services to create clouds of words facilitates the perception and memorization of new material, develops creative thinking, expands vocabulary, etc. The use of video scribing helps to increase students' interest in learning material, to facilitate the integration of new knowledge, to develop ICT skills in teaching philological disciplines. Blog integration provides an understanding of ICT tools didactic potential in students' future professional activities. What is more, ICT facilitates access to authentic materials, allows changing the content of education in accordance with the modern realities of the country whose language is studied. Therefore, the use of ICT increases motivation to master the specialty, satisfies students' communication needs. Special attention has been paid to electronic portfolio, which is an indicator of creativity, innovation and professional competence of modern teachers and allows future teachers to develop their communicative skills of self-presentation and self-reflection.

The study suggests that ICT integration in future foreign language teachers' professional training stimulates learners' cognitive interest and motivation to master their specialty, increases the effectiveness of foreign language learning, and enables knowledge assessment.

The prospects for further research are viewed in the development of linguistic disciplines educational and methodological support with ICT use in future foreign language teachers' professional training.

\section{REFERENCES (TRANSLATED AND TRANSLITERATED)}

[1] Verkhovna Rada Ukrainy. (2017, Veres. 05). Law № 2145-VII, On education. [Online]. Available: https://zakon.rada.gov.ua/laws/show/2145-19 (in Ukrainian)

[2] Verkhovna Rada Ukrainy. (2014, Lyp. 01). Law № 1556-VI, On higher education. [Online]. Available: https://zakon.rada.gov.ua/laws/show/1556-18 (in Ukrainian) 
[3] Verkhovna Rada Ukrainy. (2013, Cher. 25). Ukaz Prezydenta Ukrainy № 344/2013. On National strategy development of education in Ukraine for 2012-2021. [Online]. Available: http://oneu.edu.ua/wpcontent/uploads/2017/11/nsro_1221.pdf (in Ukrainian)

[4] Ministry of education and science of Ukraine. (2016, Zhovt. 27). Rishennia Kolehii MON. New Ukrainian School. Conceptual pronciples reform of the secondary school. [Online]. Available: https://www.kmu.gov.ua/storage/app/media/reforms/ukrainska-shkola-compressed.pdf (in Ukrainian)

[5] «European Recommendations for Language Education: Study, Teaching, Assessment». Naukovyi redaktor ukrainskoho vydannia doktor ped. nauk, prof. S.Iu.Nikolaieva. Kyiv. Ukraina: Lenvit, 2003. (in Ukrainian)

[6] V. Bykov, «Modern tasks of informatization of education». Information Technologies and Learning Tools. no.1(15), pp. 1-18, 2010. (in Ukrainian)

[7] V. Bespalko, «Computers and cyber-training» Shkolnye tekhnolohyy. no.1, pp. 3-9, 2013. (in Russian)

[8] I. Havrysh, «Theoretical and methodological bases of formation of future teachers' readiness for innovative professional activity», dys. d-ra ped. nauk, Khark. nats.. ped. un-t im. H.S.Skovorody, Kharkiv, 2006. (in Ukrainian)

[9] O. Glazunova, O. Kuzminska, T. Voloshyna, T. Sayapina, V. Korolchuk, «E-environment based on Microsoft Sharepoint for the organization of group project work of students at higher education institutions». Information Technologies and Learning Tools. no. 6, pp. 98-113, 2017. (in English)

[10] M. Zhaldak, «Problems of informatization of educational process in secondary and higher educational establishments». Kompiuter u shkoli ta simi. no.3, pp. 8-15, 2013. (in Ukrainian)

[11] E. Polat, Novye pedahohycheskye y ynformatsyonnye tekhnolohyy v systeme obrazovanyia ; pod red. Polat E.S. Moskva. Rossyia: Akademyia, 2005. (in Russian)

[12] O. Spirin, «Information and communication technology training: criteria for internal quality assessment». Information Technologies and Learning Tools. no.5 (19), pp. 1-12, 2010. [Online]. Available: http://www.ime.edu-ua.net/em.html. Accessed on: Oct. 15, 2019. (in Ukrainian)

[13] I. Kostikova, A. Masliuk, «Professional-pedagogical competence of the future foreign language teacher in the conditions of introduction of information and communication technologies». Kharkiv, Ukraina: Tsyfrova drukarnia no.1, 2009. (in Ukrainian)

[14] I. Khyzhniak, «Peculiarities of linguo-didactic competence of modern elementary school teacher and ways of its formation». Naukovyi Visnyk Volynskoho natsionalnoho universytetu imeni Lesi Ukrainky : Pedahohichni nauky. no. 14 (239), pp.198-200, 2012. (in Ukrainian)

[15] O. Kucheruk, S. Karaman, O. Karaman, N. Vinnikova, «Use of ICT for the formation of professional competences in future teachers of Ukrainian language and literature». Information Technologies and Learning Tools. vol. 71, no.3. pp. 196-214. 2019. (in Ukrainian)

[16] N. Morze, O. Kuzminska,V. Vember, O. Barna, «Competence tasks as a means of informational competence formation in conditions of continuing education». Information Technologies and Learning Tools. no.4, pp. 48-62, 2010.

[17] Kiv, A.E., Semerikov, S.O., Soloviev, V.N., Striuk, A.M.: First student workshop on computer science \& software engineering. In: Kiv, A.E., Semerikov, S.O., Soloviev, V.N., Striuk, A.M. (eds.) Proceedings of the 1st Student Workshop on Computer Science \& Software Engineering (CS\&SE@SW 2018), Kryvyi Rih, Ukraine, November 30, 2018. CEUR Workshop Proceedings 2292, pp. 1-10. [Online]. Available: http://ceur-ws.org/Vol-2292/paper00.pdf (2018). Accessed on: Dec. 31, 2018. (in English)

[18] V. Bykov, Modeli orhanizatsiinykh system vidkrytoi osvity. Kyiv, Ukraina: Atika. 2008. (in Ukrainian)

[19] O. Romanovskyi, V. Hrynova, O. Rezvan, «Mental cards as an innovative way of organizing information in higher education». Information Technologies and Learning Tools. vol. 64, no.2, pp. 185-196, 2018. (in Ukrainian)

[20] O. Dubaseniuk, T. Semeniuk, O. Antonova, Professional preparation of future teacher for pedagogical activity. Zhytomyr, Ukraina: Zhytomyrskyi derzh. ped. un-t, 2003. (in Ukrainian)

[21] I. Kostikova, «Theoretical and methodological principles of professional training of future foreign language teachers by means of information and communication technologies», avtoref. dys. d-ra ped. nauk., Khark. nats. ped. un-t imeni H.S. Skovorody, Kharkiv, 2009. (in Ukrainian)

[22] L. Morska, «Theoretical and methodological bases of preparation of future foreign language teachers for the use of information technologies in professional activity», avtoref. dys. d-ra ped. nauk, Ternop. nats. ped. un-t imeni Volodymyra Hnatiuka, Ternopil, 2008. (in Ukrainian)

[23] National doctrine of education development of Ukraine in XXI century. Osvita Ukrainy. 2002. no. 33. 23 kvitnia. [Online]. Available: https://zakon.rada.gov.ua/laws/show/347/2002\#Text (in Ukrainian)

[24] N. Ostapenko, «Theoretical and methodological bases of formation of linguo-didactic competence in future teachers of Ukrainian language and literature», avtoref. dys. d-ra ped. nauk: spets. Kyivsk. linhvist. un-t , Kyiv, 2010. (in Ukrainian) 
[25] O. Kopus, «Theoretical and methodological bases of formation of professional linguo-didactic competence of future masters-philologists», dys...doktora ped. nauk. DZ «Pivdennoukrainskyi natsionalnyi pedahohichnyi universytet imeni K. D. Ushynskoho», Odesa, 2013. (in Ukrainian)

Матеріал надійшов до редакиії 02.04.2020p.

\title{
ВИКОРИСТАННЯ ІНФОРМАЦІЙНО-КОМУНІКАЦІЙНИХ ТЕХНОЛОГІЙ ДЛЯ ФОРМУВАННЯ ЛІНГВОДИДАКТИЧНОЇ КОМПЕТЕНТНОСТІ МАЙБУТНІХ УЧИТЕЛІВ ІНОЗЕМНОЇ МОВИ
}

\author{
Вакалюк Тетяна Анатоліївна \\ доктор педагогічних наук, професор, професорка кафедри інженерії програмного забезпечення \\ Державний університет «Житомирська політехніка», м. Житомир, Україна \\ ORCID ID 0000-0001-6825-4697 \\ tetianavakaliuk@gmail.com \\ Осова Ольга Олексіївна \\ доктор педагогічних наук, доцент, доцентка кафедри іноземної філології \\ Комунальний заклад «Харківська гуманітарно-педагогічна академія» Харківської обласної ради \\ м. Харків, Україна \\ ORCID ID 0000-0001-7316-1196 \\ osova.olga@gmail.com
}

Черниш Оксана Андріївна

кандидат філологічних наук, доцентка кафедри теоретичної та прикладної лінгвістики Державний університет «Житомирська політехніка», м. Житомир, Україна ORCID ID 0000-0002-2010-200X

chernyshoxana@gmail.com

\begin{abstract}
Анотація. У статті досліджується проблема використання інформаційно-комунікаційних технологій $з$ метою формування лінгводидактичної компетентності майбутніх учителів іноземної мови. На основі аналізу науково-педагогічних джерел обгрунтовано актуальність та доведено важливість запровадження інформаційно-комунікаційних технологій під час підготовки майбутніх учителів іноземної мови. Емпіричними методами (анкетування, спостереження, опитування) з'ясовано сучасний стан використання інформаційнокомунікаційних технологій під час фахової підготовки майбутніх учителів іноземної мови. Уточнено сутність ключових понять дослідження: «інформаційно-комунікаційні технології», «професійно-педагогічна компетентність», «лінгводидактична компетентність майбутніх учителів іноземних мов». Представлено досвід запровадження інформаційнокомунікаційні технології як одного з найважливіших засобів формування лінгводидактичної компетентності в процес підготовки майбутніх учителів іноземної мови. Установлено, що інформаційно-комунікаційні технології навчального призначення (мультимедійні презентації, хмарні сервіси, блог, відеоскрайбінг, електронне портфоліо, вебквести тощо) надають широкі дидактичні можливості для формування лінгводидактичної компетентності майбутніх учителів іноземної мови, а саме створюють умови для оброблення іншомовних ділових документів, моделювання віртуального середовища ділового спілкування іноземною мовою, отримання відомостей (навчальних, країнознавчих, лінгвістичних), сприяння усім видам мовленнєвої діяльності (читання, говоріння, аудіювання, письмо), презентації та пошуку даних про мови та країни тощо. Окремо акцентовано увагу на такому виді роботи 3 інформаційно-комунікаційними технологіями, як створення власного електронного портфоліо, що $є$ показником творчості, інноваційності та професійної компетентності сучасного педагога і дає змогу майбутнім учителям-словесникам розвивати комунікативні навички самопрезентації та саморефлексії. Виявлено та експериментально перевірено ефективність використання інформаційно-комунікаційних технологій з метою формування лінгводидактичної компетентності майбутніх учителів іноземної мови.
\end{abstract}

Ключові слова: інформаційно-комунікаційні технології; лінгводидактична компетентність; майбутні вчителі іноземної мови; електронне портфоліо. 


\title{
ИСПОЛЬЗОВАНИЕ ИНФОРМАЦИОННО-КОММУНИКАЦИОННЫХ ТЕХНОЛОГИЙ ДЛЯ ФОРМИРОВАНИЯ ЛИНГВОДИДАКТИЧЕСКОЙ КОМПЕТЕНТНОСТИ БУДУЩИХ УЧИТЕЛЕЙ ИНОСТРАННОГО ЯЗЫКА
}

\author{
Вакалюк Татьяна Анатольевна \\ доктор педагогических наук, профессор, профессор кафедры инженерии парограммного обеспечения \\ Государственный университет «Житомирская политехника», г. Житомир, Украина \\ ORCID ID 0000-0001-6825-4697 \\ tetianavakaliuk@gmail.com
}

\section{Осовая Ольга Алексеевна}

доктор педагогоческих наук, доцент, доцент кафедры иностранной филологи

Коммунальное учреждение «Харьковская гуманитарно-педагогическая академия» Харьковского обласного совета, г. Харьков, Украина

ORCID ID 0000-0001-7316-1196

osova.olga@gmail.com

\author{
Черныш Оксана Андреевна \\ кандидат филологических наук, доцент кафедры теоретической и прикладной лингвистики \\ Государственный университет «Житомирская политехника», г. Житомир, Украина \\ ORCID ID 0000-0002-2010-200X \\ chernyshoxana@gmail.com
}

\begin{abstract}
Аннотация. В статье исследуется проблема использования информационнокоммуникационных технологий с целью формирования лингводидактической компетентности будущих учителей иностранного языка. На основе анализа научнопедагогических источников обоснована актуальность и доказана важность внедрения информационно-коммуникационных технологий при подготовке будущих учителей иностранного языка. Эмпирическими методами (анкетирование, наблюдение, опрос) установлены современные условия использования информационно-коммуникационных технологий во время профессиональной подготовки будущих учителей иностранного языка. Определена сущность ключевых понятий исследования: «информационнокоммуникационные технологии», «профессионально-педагогическая компетентность», «лингводидактическая компетентность будущих учителей иностранных языков». Исходя из положения о том, что информационно-коммуникационные технологии выступают одним из важнейших средств формирования лингводидактической компетентности будущих учителей иностранного языка, мы представили опыт их внедрения в процесс подготовки будущих учителей иностранного языка. В процессе исследования установлено, что информационно-коммуникационные технологии учебного назначения (мультимедийные презентации, облачные сервисы, блог, видеоскрайбинг, электронное портфолио, вебквесты и т.д.) предоставляют широкие дидактические возможности для формирования лингводидактической компетентности будущих учителей иностранного языка, а именно: создают условия для обработки деловой документации на иностранном языке, моделирования виртуальной среды делового общения на иностранном языке, получения сведений (учебных, страноведческих, линвистических), содействия всем видам речевой деятельности (чтение, говорение, аудирование, письмо), презентации и поиска данных о языках и страны и т.п. Отдельно акцентировано внимание на таком виде работы с информационно-коммуникационными технологиями, как создание собственного электронного портфолио, которое является показателем творчества, инновационности и профессиональной компетентности современного педагога и позволяет будущим учителямфилологам развивать коммуникативные навыки самопрезентации и саморефлексии. Выявлена и экспериментально проверена эффективность использования информационнокоммуникационных технологий с целью формирования лингводидактической компетентности будущих учителей иностранного языка.
\end{abstract}

Ключевые слова: информационно-коммуникационные технологии; лингводидактическая компетентность; будущие учителя иностранного языка; электронное портфолио.

\section{$(\mathrm{cc}) \mathrm{EY}$ B-NC-SA}

ThisworkislicensedunderCreativeCommonsAttribution-NonCommercial-ShareAlike 4.0 InternationalLicense. 